\title{
Penggunaan Kultur Starter Bakteri Asam Laktat pada Pengolahan Sosis Fermentasi Ikan Lele Dumbo yang Diinfeksi Listeria monocytogenes ATCC-1194
}

\author{
Happy Nursyam* \\ Jurusan Teknologi Hasil Perikanan, Fakultas Perikanan dan Ilmu Kelautan, Universitas Brawijaya, Malang
}

\begin{abstract}
Abstrak
Penggunaan biopreservatif bakteri asam laktat pada bahan makanan sangat efektif dalam mengontrol pertumbuhan bakteri patogen dan mikroorganisme pembusuk. Bakteri asam laktat pada produk fermentasi, selain berperan sebagai biopreservatif juga berperan penting dalam meningkatkan kualitas nutrisi bahan mentah yang difermentasi. Penelitian ini merupakan kajian tentang penggunaan kultur starter Pediococcus acidilactici; Lactobacillus casei; dan kombinasi Pediococcus acidilactici dan Lactobacillus casei; serta tanpa starter kultur sebagai kontrol, terhadap karakter biopreservatif sosis fermentasi ikan lele dumbo yang diinfeksi Listeria monocytogenes selama pematangan 28 hari pada suhu inkubasi $15-22{ }^{\circ} \mathrm{C}$. Berdasarkan hasil penelitian diketahui komponen biopreservatif yang dihasilkan didominasi oleh senyawa alkohol, keton, asam-asam lemak, ester dari asam lemak, fenol, benzene, dan senyawa volatil lain. Fenol merupakan senyawa yang terbanyak. Semakin besar rasio C15:0/C17:0 dalam sosis fermentasi ikan lele dumbo, pertumbuhan Listeria monocytogenes makin sedikit. Sosis yang difermentasi menggunakan kombinasi Pediococcus acidilactici dan Lactobacillus casei starter memiliki rasio C15:0/C17:0 terbesar, dan mampu mematikan pertumbuhan Listeria monocytogenes. Rasio C15:0/C17:0 dengan nilai 79,84 merupakan dosis yang mematikan bagi Listeria monocytogenes pada suhu inkubasi $15-21,2{ }^{\circ} \mathrm{C}$ secara in vitro.
\end{abstract}

Kata kunci: BAL, biopreservatif, Ikan Lele Dumbo, Listeria monocytogenes

\section{PENDAHULUAN}

Sosis ikan merupakan sebuah produk, yang berasal dari daging ikan segar dicampur dengan beberapa aditif, kemudian dimasukkan ke dalam casing dan diproses melalui pemanasan [1]. Pengolahan sosis ikan mulai berkembang pesat pada tahun 1950 sampai 1975 di Jepang, dan merupakan pengembangan dari industri kamaboko [2]. Perlakuan panas yang diberikan pada pengolahan sosis ikan pada suhu $88-90{ }^{\circ} \mathrm{C}$ selama 45 menit, belum cukup untuk membunuh atau menghambat pertumbuhan spora bakteri pembusuk, sehingga pada era tahun 1980 dikembangkan penggunaan suhu tinggi, namun masih terjadi hambatan terutama biaya yang sangat tinggi dan menurunnya karakter tekstur produk akhir [3].

Penggunaan strain bakteri penghasil bakteriosin sebagai kultur starter atau protektif kultur, akhir-akhir ini banyak dikembangkan dan mampu mengontrol keberadaan bakteri patogen

\footnotetext{
* Alamat Korespondensi

Happy Nur Syam

E-mail : happy_nursyam@yahoo.com

Alamat : Jurusan Teknologi Hasil Perikanan, Fakultas Perikanan dan Ilmu Kelautan, Universitas Brawijaya, Jl.Veteran, Malang
}

maupun bakteri pembusuk dalam produk pangan siap saji (Hugas, 1995). Kultur strain yang digunakan sebagian besar berasal dari bakteri asam laktat, antara lain Lactobacillus, Pediococcus, Lactococcus, Leuconostoc, dan Carnobacterium, tetapi penggunaan kultur starter BAL yang tidak tepat belum mampu menghambat pertumbuhan Listeria monocytogenes pada sosis $[4,5,6,7,8,9]$.

Penggunaan biopreservatif bakteri asam laktat ke dalam sistem pangan terlihat sangat efektif dalam mengontrol pertumbuhan bakteri patogen dan mikroorganisme pembusuk. Bakteri asam laktat pada produk fermentasi, selain berperan sebagai biopreservatif juga penting peranannya dalam meningkatkan kualitas nutrisi bahan mentah yang difermentasi [10]. Penghambatan terhadap pertumbuhan bakteri patogen dan pembusuk diakibatkan oleh biopreservatif yang diproduksi bakteri asam laktat, seperti asam laktat, asam asetat, hidrogen peroksida, diasetil dan bakteriosin [11]. Bakteri yang memproduksi bakteriosin sebagai antimikroba terhadap Listeria monocytogenes diantaranya Lactococcus lactis, Lactobacillus bavaricus, Lactobacillus reuteri, Lactobacillus acidophilus, Lactobacillus curvatus, Lactobacillus 
sake, Lactobacillus plantarum, Leuconostoc carnosum, Leuconostoc mesenteroides, Carnobacterium piscicola, Pediococcus acidilactici, Propionibacterium thoenii, dan Enterococcus spp. [10]. Penelitian ini merupakan kajian tentang penggunaan kultur starter Pediococcus acidilactici 0094<TGA-3; actobacillus casei NRRL-B1992; dan kombinasi Pediococcus acidilactici 0094<TGA-3 dan actobacillus casei NRRL-B1992; serta tanpa starter kultur sebagai kontrol, terhadap karakter biopreservatif sosis fermentasi ikan lele dumbo yang diinfeksi Listeria monocytogenes ATCC-1194 selama 28 hari pada suhu inkubasi $15-22^{\circ} \mathrm{C}$.

\section{METODE PENELITIAN \\ Kultur bakteri}

Pediococcus acidilactici 0094<TGA-3 (PA), Lactobacillus casei NRRL-B1992 (LC), dan Listeria monocytogenes ATCC-1194 (LM), diperoleh dari PAU (Pusat Antar Universitas) pangan dan gizi, Universitas Gajahmada-Yogyakarta. PA dikultur pada MRS broth (Oxoid) suhu $30{ }^{\circ} \mathrm{C}$, dan Listeria monocytogenes pada $\mathrm{BHI}$ broth (Oxoid) yang ditambahkan $\mathrm{NaCl} 3 \%$ pada suhu $37{ }^{\circ} \mathrm{C}$. Sel bakteri dipanen setelah 24 jam inkubasi, dan dilarutkan ke dalam pepton $0,1 \%$ steril untuk mendapatkan konsentrasi yang diinginkan.

Preparasi sosis

Lele dumbo segar (Clarias gariepinus) yang didapat dari penangkar kota Batu-Jawa Timur dipotong kepalanya, dikuliti dan difilet, kemudian dicincang menggunakan blender (Phillip), selanjutnya preblending. Formula sosis untuk 1000 gram lele adalah: $\mathrm{NaCl} 20 \mathrm{~g}$, sodium nitrat $0,2 \mathrm{~g}$, sodium nitrit $0,1 \mathrm{~g}$, sukrosa $4 \mathrm{~g}$, glukosa $3 \mathrm{~g}$, fruktose $3 \mathrm{~g}$, lada putih $1 \mathrm{~g}$, lada hitam $1 \mathrm{~g}$, lengkuas $0,7 \mathrm{~g}$, jahe $0,7 \mathrm{~g}$, kayu manis $0,6 \mathrm{~g}$, bawang putih $0,5 \mathrm{~g}$, dan cengkeh $0,5 \mathrm{~g}$. Resep tersebut diambil berdasarkan Aryanta, et al., (1991), dengan modifikasi formula dan proses oleh Nursyam, et al., (2006 dan 2007) [12, 13, 14]. Semua bahan tersebut dicampur dengan lele cincang, kemudian ditambahkan kultur starter $P$. acidilactici dan Lactobacillus casei masing-masing $10^{8}$ cfuml $^{-1}$ sebanyak $2 \mathrm{ml}$ untuk $500 \mathrm{~g}$ daging. Listeria monocytogenes ATCC-1194 masing $2 \mathrm{ml}$ $10^{5}$ cfuml $^{-1}$ diinokulasikan secara individual kedalam sosis, selanjutnya adonan dimasukkan casing kolagen diameter $2 \mathrm{~cm}$ sepanjang $10 \mathrm{~cm}$, pra-inkubasi, pengasapan, dan diinkubasi pada suhu komersial $\left(15-22^{\circ} \mathrm{C}\right)$ selama 28 hari.

Analisa Biopreservatif

Kajian biopreservatif sosis fermentasi ikan lele diamati melalui 2 percobaan yaitu identifikasi komponen biopreservatif menggunakan GC-MS (Shimadzu 20), dan pengujian Minimum Bactericidal Concentration (MBC) biopreservatif terhadap Listeria monocytogenes secara in-vitro. Pengujian komponen biopreservatif dianalisis dengan menggunakan "Gas Chromatography Mass Spectrometri". Sebanyak $2 \mu \mathrm{L}$ sampel sosis hasil refluksi diinjeksikan dalam GCMS (Shimadzu QP2010S).

Minimum Bactericidal Concentration komponen biopreservatif terhadap survival (log) Listeria monocytogenes, dianalisis berdasar modifikasi metode dari Nichols et al., (2003) untuk persiapan media, Erkkila et al., (2001) untuk survival Listeria monocytogenes; dan Kronvall (1982) untuk penarikan $\operatorname{MBC}[9,15,16]$. Survival Listeria monocytogenes terhadap rasio C15:0/C17:0 diukur menggunakan metode spread, setelah ditaman dan diinkubasi 48 jam pada media TSA-Oxoid $37{ }^{\circ} \mathrm{C}$. Minimum konsentrasi antimikroba bagi Listeria monocytogenes dari asam lemak didefinisikan sebagai rasio C15:0/C17:0 yang tidak terdapat pertumbuhan koloni Listeria monocytogenes setelah diinkubasi 48 jam pada suhu $37^{\circ} \mathrm{C}$ [17].

\section{Analisis Data}

Data dianalisis secara deskriptif berdasarkan rerata \pm standar deviasi diantara variabel independen percobaan, menggunakan microsoft excell.

\section{HASIL DAN PEMBAHASAN}

Hasil analisis Kromatogram senyawa volatil dan asam lemak sosis fermentasi ikan lele dumbo, disajikan pada Tabel 1. Data dalam Tabel 1 menunjukkan bahwa fenol dan derivat fenol merupakan komponen terbanyak pada semua jenis sosis. Hal ini disebabkan fenol adalah senyawa pyrolisis dari lignin tempurung kelapa yang mampu terikat dalam asam-asam lemak. Hamm (1977) menyatakan bahwa semakin tinggi keasaman suatu produk, makin tinggi fenol yang terikat [18]. Terbentuknya senyawa metilpalmitat pada sosis, diduga akibat interaksi antara asam palmitat (C16:0) dengan minyak atsiri yang terkandung dalam ketumbar. Harris et al., (1989) menyatakan bahwa ketumbar (Coriandrum sativum) mengandung 0,5\% - 1\% minyak atsiri [6].

Sosis yang difermentasi menggunakan kombinasi Ped. acidilactici dan $L$ b. casei starter (kolom VI) mengandung lebih banyak senyawa alkohol, asam, phenol, dan benzene. Sosis yang difermentasi menggunakan kultur starter Ped. 
acidilactici (kolom V) lebih banyak mengandung senyawa keton; sedangkan indigenous sosis (kolom IV) lebih banyak pada senyawa ester. Apabila dibandingkan dengan reference (kolom III), sebagian besar masih berada dibawahnya, kecuali phenol, asam lemak, dan toluene. Komponen volatil dan asam lemak pada sosis fermentasi ikan lele dumbo ini rendah diduga enzim eksogeneus (protease dan lipase) dari BAL tidak cukup untuk memunculkan volatil dan asam lemak yang lebih banyak.
Senyawa volatil dan asam lemak sosis fermentasi terbanyak adalah fenol, kemudian keton, asam lemak, ester, fenol, benzene, alkohol, dan benzene acetic acid (Tabel 1.). Montel et al. (1999), menyatakan volatil dan asam lemak dibentuk oleh reaksi enzimatis (glikolisis, proteolisis, oksidatif deaminasi, transaminasi, dan dekarboksilasi) atau proses kimia (oksidasi lemak, degradasi protein, dan reaksi Maillard) yang terjadi selama pematangan sosis [19].

Tabel 1. Data kadar senyawa volatil dan asam lemak (ppm) sosis fermentasi ikan lele dumbo pada ahir inkubasi

\begin{tabular}{|c|c|c|c|c|c|c|c|c|c|c|}
\hline \multirow{4}{*}{ No. } & \multirow{4}{*}{$\begin{array}{l}\text { Komponen } \\
\text { lemak }\end{array}$} & \multirow{4}{*}{ volatil dan } & \multirow{4}{*}{$\begin{array}{l}\text { Rumus } \\
\text { Molekul }\end{array}$} & \multirow{4}{*}{$\begin{array}{l}\text { Refe- } \\
\text { ren }\end{array}$} & \multicolumn{6}{|c|}{ Listeria monocytogenes } \\
\hline & & & & & \multirow{2}{*}{\multicolumn{3}{|c|}{$\begin{array}{l}\text { Tanpa } \\
\text { Starter Kultur Sosis }\end{array}$}} & \multicolumn{2}{|c|}{ Diinfeksi } & \\
\hline & & & & & & & \multicolumn{3}{|c|}{ Starter Kultur Sosis } & \multirow[b]{2}{*}{$\mathrm{PA}+\mathrm{LC}$} \\
\hline & & & & & $\begin{array}{l}\text { Indige } \\
\text { nous }\end{array}$ & PA & $\mathrm{PA}+\mathrm{LC}$ & $\begin{array}{l}\text { Indige } \\
\text { nous }\end{array}$ & PA & \\
\hline 1 & II & & & III & IV & V & $\mathrm{VI}$ & VII & VIII & $I X$ \\
\hline \multirow[t]{3}{*}{1.} & \multirow[t]{3}{*}{ Alkohol } & Furyl alkohol & $\mathrm{C}_{5} \mathrm{H}_{6} \mathrm{O}_{2}$ & $191^{b}$ & 14 & 15.5 & 9 & 17 & 11,5 & 29 \\
\hline & & Ethanol & $\mathrm{C}_{8} \mathrm{H}_{10} \mathrm{O}$ & $44^{\mathrm{a}}$ & & 24 & 31 & 33.6 & 31,5 & 55 \\
\hline & & JUMLAH & & & 14 & 39.5 & 40 & 50.6 & 43 & 84 \\
\hline \multirow[t]{4}{*}{2.} & \multirow[t]{4}{*}{ Keton } & \multirow{2}{*}{$\begin{array}{l}\text { Corylone } \\
\text { 3-Ethyl-2-hydroxy-2- } \\
\text { cyclopentene-1-one }\end{array}$} & $\mathrm{C}_{6} \mathrm{H}_{8} \mathrm{O}_{2}$ & $276^{a}$ & 56 & 72.5 & 65 & 55 & 52,5 & 55,5 \\
\hline & & & $\mathrm{C}_{7} \mathrm{H}_{10} \mathrm{O}_{2}$ & $\mathrm{Nd}$ & 27 & 32 & 31.5 & 28 & 31,5 & 6 \\
\hline & & $\begin{array}{l}\text { 3-Decen-2-one; } \\
\text { ethanon }\end{array}$ & $\begin{array}{l}\mathrm{C}_{11} \mathrm{H}_{21} \mathrm{~N} \\
\mathrm{O}\end{array}$ & $\mathrm{Nd}$ & 13.5 & 20 & 12.5 & 16.8 & 15,5 & 19 \\
\hline & & $J U M L A H$ & & & 96.5 & 124.5 & 109 & 99.8 & 99,5 & 80,5 \\
\hline \multirow[t]{2}{*}{3.} & \multirow{2}{*}{$\begin{array}{l}\text { Fatty } \\
\text { Acids }\end{array}$} & Pentadecanoic acid & $\mathrm{C}_{15} \mathrm{H}_{30} \mathrm{O}_{2}$ & $37^{\mathrm{a}}$ & 430 & 418 & 588.5 & 494.5 & 588 & 192,5 \\
\hline & & $\begin{array}{l}\text { Hexadecanoic acid } \\
\text { JUMLAH }\end{array}$ & $\mathrm{C}_{16} \mathrm{H}_{32} \mathrm{O}_{2}$ & $186^{\mathrm{a}}$ & $\begin{array}{l}222.5 \\
652,5\end{array}$ & $\begin{array}{l}162 \\
580\end{array}$ & $\begin{array}{l}186 \\
774,5\end{array}$ & $\begin{array}{l}171.5 \\
666\end{array}$ & $\begin{array}{l}228,5 \\
814,5\end{array}$ & $\begin{array}{l}141 \\
333,5\end{array}$ \\
\hline 4. & $\begin{array}{l}\text { Ester - } \\
\text { Fatty }\end{array}$ & $\begin{array}{l}\text { Hexadecanoic acid; } \\
\text { Methyl ester }\end{array}$ & $\mathrm{C}_{17} \mathrm{H}_{34} \mathrm{O}_{2}$ & $209^{a}$ & 254 & 138 & 40,5 & 128 & 116.5 & - \\
\hline & acid & $\begin{array}{l}\text { Dodecanoic acid; } \\
\text { Ethyl ester }\end{array}$ & $\mathrm{C}_{14} \mathrm{H}_{28} \mathrm{O}_{2}$ & $351^{b}$ & 44,5 & 28 & 46 & 46.5 & 48,5 & 52,5 \\
\hline & & $J U M L A H$ & & & 298,5 & 166 & 86,5 & 174,5 & 165 & 52,5 \\
\hline 5. & Phenol & Phenol & $\mathrm{C}_{6} \mathrm{H}_{6} \mathrm{O}$ & $121^{\mathrm{a}}$ & 1529 & 1738,5 & 1656 & 1512 & 1483,5 & 1516 \\
\hline & & Guajol & $\mathrm{C}_{7} \mathrm{H}_{8} \mathrm{O}_{2}$ & $182^{b}$ & 383 & 397 & 361,5 & 366,5 & 380,5 & 465 \\
\hline & & Eugenol & $\mathrm{C}_{10} \mathrm{H}_{12} \mathrm{O}_{2}$ & $99^{b}$ & 445,5 & 426,5 & 435,5 & 486.5 & 458 & 586,5 \\
\hline & & Isoeugenol & $\mathrm{C}_{10} \mathrm{H}_{12} \mathrm{O}_{2}$ & $207^{a}$ & 131 & 110,5 & 95,5 & 125 & 103 & 155,5 \\
\hline & & $\begin{array}{l}\text { 2-methoxy-4-methyl- } \\
\text { phenol }\end{array}$ & $\mathrm{C}_{8} \mathrm{H}_{10} \mathrm{O}_{2}$ & $264^{b}$ & 221,5 & 218 & 199 & 220 & 207,5 & 272 \\
\hline & & $\begin{array}{l}\text { 4-ethyl-2-methoxy- } \\
\text { phenol }\end{array}$ & $\mathrm{C}_{9} \mathrm{H}_{12} \mathrm{O}_{2}$ & $654^{b}$ & 139 & 134 & 118 & 156 & 133,5 & 186 \\
\hline & & 4-methyl-phenol & $\mathrm{C}_{7} \mathrm{H}_{8} \mathrm{O}$ & $52^{\mathrm{a}}$ & 124,5 & 136,5 & 132 & 139,5 & 136 & 145 \\
\hline & & 3-methyl-phenol & $\mathrm{C}_{7} \mathrm{H}_{8} \mathrm{O}$ & $123^{a}$ & 70,5 & 74,5 & 78,5 & 75 & 68,5 & 76 \\
\hline & & 2-methyl-phenol & $\mathrm{C}_{7} \mathrm{H}_{8} \mathrm{O}$ & $93^{\mathrm{a}}$ & 70 & 59,5 & 68 & 75 & 75 & 88,5 \\
\hline & & JUMLAH & & & 3114 & 3295 & 3144 & 3155,5 & 3045,5 & 3490,5 \\
\hline 6. & Benzene & Toluene & $\mathrm{C}_{6} \mathrm{H}_{6} \mathrm{O}_{4} \mathrm{~S}$ & $24^{a}$ & 160,5 & 180,5 & 173 & 170 & 174,5 & 182,5 \\
\hline & & Syringol & $\mathrm{C}_{8} \mathrm{H}_{10} \mathrm{O}_{3}$ & $152^{\mathrm{b}}$ & 644,5 & 609 & 646 & 661 & 624,5 & 658,5 \\
\hline & & $J U M L A H$ & & & 805 & 789,5 & 819 & 831 & 799 & 841 \\
\hline 7. & $\begin{array}{l}\text { Various } \\
\text { volatil }\end{array}$ & Benzene acetic acid & $\mathrm{C}_{11} \mathrm{H}_{14} \mathrm{O}_{4}$ & $93^{b}$ & 14,5 & 5,5 & 13,5 & 16,5 & 15 & 25,5 \\
\hline Rasio & & C15:0/C17:0 & & & 1,69 & 3,03 & 14,53 & 3,86 & 5,05 & $*$ \\
\hline & terangan: & & & & & & & & & \\
\hline & И : Listeria $m$ & nonocytogenes & & & ) & : Tidak te & ingga & & & \\
\hline $\mathrm{P}$ & A : Pediococc & us acidilactici & & & & & & & & \\
\hline $\mathrm{L}$ & : : Lactobacil & Illus casei. & & & & & & & & \\
\hline a) & : Schmidt d & dan Berger (1998) & & & & & & & & \\
\hline b) & : Ansoeren & a, et al. (2000) & & & & & & & & \\
\hline $\mathrm{N}$ & : No data & & & & & & & & & \\
\hline
\end{tabular}


Metil palmitat sosis kombinasi Pediococcus acidilactici dan Lactobacillus casei starter (tanpa diinfeksi Listeria monocytogenes) lebih kecil dibanding sosis indigenous dan Ped. acidilactici starter. Begitu juga yang diinfeksi Listeria monocytogenes, kecuali sosis kombinasi Ped. acidilactici dan Lb. casei starter (kolom IX) tidak dijumpai senyawa hexadecanoic acid-metil ester (metil palmitat). Menurut Sasser (1990), metil palmitat terletak diantara prokariot Listeria monocytogenes [20]. Welch (1991), menyatakan bahwa L. monocytogenes dikarakterisasi oleh ranting ikatan CFAs yang panjangnya 15 dan 17 [21]. Listeria monocytogenes disusun oleh $\mathrm{C}_{15}$ dan $\mathrm{C}_{17}$ sebagai komponen utama, dan $88 \%$ asam lemak yang terkandung bersifat polar-lipid, $46 \%$ sebagai anteiso C15:0; $24 \%$ sebagai anteiso C17:0; dan $11 \%$ sebagai iso C15:0 [22]. Persentase komponen $\mathrm{C} 17: 0$ meningkat linier seiring dengan peningkatan pertumbuhan pada kondisi lingkungan yang sesuai [15].

Semakin besar rasio C15:0/C17:0 pada sosis fermentasi, semakin sedikit kandungan Listeria monocytogenes (Tabel 1) pada sosis fermentasi. Hal ini mengindikasikan hidro-fobisitas berperan dalam tranportasi lipid ke dalam membran sel Listeria monocytogenes. Tabel 5.19 (kolom VI) tertera bahwa rasio $\mathrm{C} 15: 0 / \mathrm{C} 17: 0$ lebih besar dibanding indigenous dan Ped. acidilactici starter (kolom IV dan V). Keadaan ini menyebabkan karakter C15:0 yang kurang hidrofobik dibanding C17:0 berperan semakin kuat, sehingga transfer lipid melalui membran fosfolipid Listeria monocytogenes menjadi berkurang. Kondisi ini memperkuat hasil percobaan 8 (Gambar 1), bahwa Listeria monocytogenes tidak mampu beraktifitas, dan ahirnya mati. Rasio 1,69 pada indigenous sosis (kolom IV) adalah paling hidrofobik dibanding lainnya, sehingga Listeria monocytogenes dapat tumbuh dan berkembang biak (Tabel 1).

Membran sel bakteri gram negatif terdiri dari bilayer fosfolipid [23]. Semakin berkurang karakter hidrofobik asam lemak C15:0/C17:0 semakin sulit menembus fosfolipid bilayer. Membran fosfolipid terdiri dari rantai acyl yang bersama-sama membentuk kesatuan yang kuat dan molekul air mampu berpenetrasi ke dalamnya. Protein dikirim kedalam membran melalui matriks fosfolipid, juga di degradasi dan dikeluarkan dari membran dengan adanya enzim proteolitik [21]. Komposisi dan tipe asam lemak bakteri dibebedakan pada derivat rantai karbon dari gliserol. Derivat yang terbentuk adalah dimetil acetat dan metil ester [25].

Perubahan rasio protein atau lemak dan asam lemak jenuh atau tidak jenuh dalam membran lipid L. monocytogenes, dapat mempengaruhi fluiditas membran fosfolipid [22]. Oleh karena ketersediaan hexadecanoid acid (Tabel 1) pada sosis yang difermentasi dengan kombinasi kultur starter Pediococcus acidilactici dan Lactobacillus casei (kolom VI) lebih kecil dibanding dua sosis lainnya (kolom IV dan V) menyebabkan Listeria monocytogenes tidak dijumpai pada ahir fermentasi (kolom IX). Hal ini sesuai dengan pernyataan Mastronicolis, et al. (1996), bahwa penurunan proporsi C17:0 anteiso berpengaruh terhadap aktifitas transpor dalam membran lipid, sehingga tidak tercapainya rasio C15:0/C17:0 yang seharusnya 1,5 menyebabkan penurunan pertumbuhan L. monocytogenes [24].

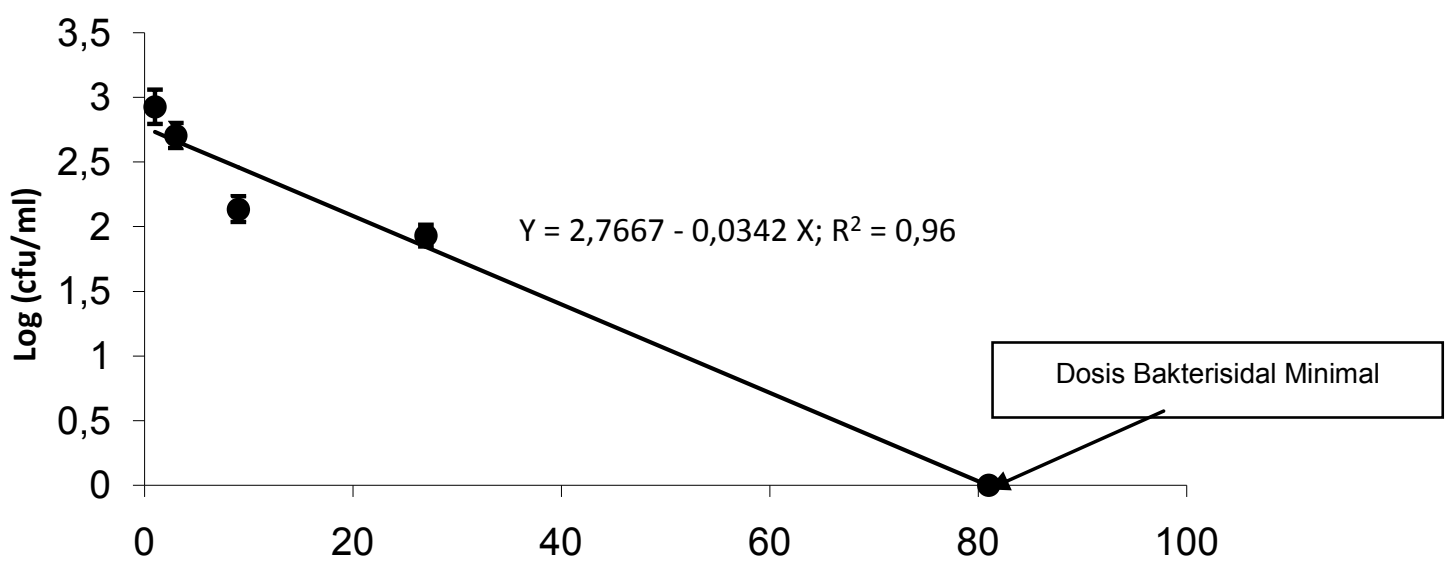

Rasio C15:0/C17:0

Gambar 1. Plot kuadrat penghambatan kelangsungan hidup (log) Listeria monocytogenes terhadap rasio C15:0/C17:0. - : data pengamatan. Bar adalah SD. 
A.

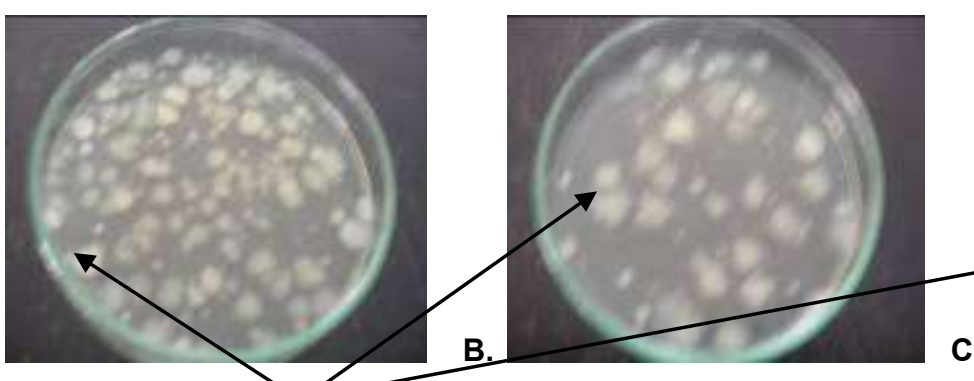

D.

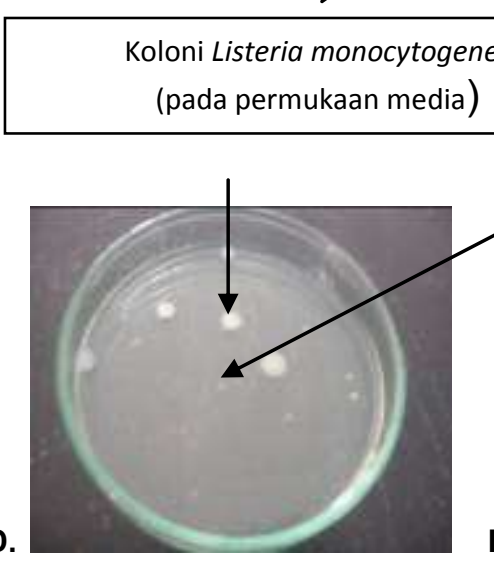

c.

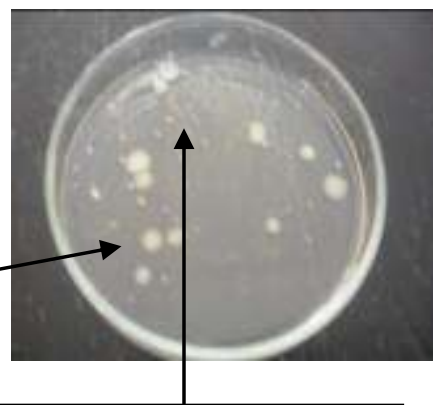

Koloni bakteri Lain

(dibawah permukaan media)

Gambar 2. Koloni Listeria monocytogenes pada media blood agar; Merck (Pengenceran 10-1 ). Rasio C15:0/C17:0 = 1 (A); 3 (B); 9 (C); 27 (D); dan 81 (E). Foto diambil pada 48 hari inkubasi menggunakan kamera digital "Logitech" 510.

Hasil pengujian rasio $\mathrm{C} 15: 0 / \mathrm{C} 17: 0$ terhadap kelangsungan hidup Listeria monocytogenes yang diinkubasi pada suhu $15-21,2{ }^{\circ} \mathrm{C}$, terdapat pada Gambar 1 dan 2. Berdasarkan persamaan garis regresi pada Gambar 1, diperoleh bahwa rasio C15:0/C17:0 dengan nilai 79,84 merupakan Minimum Bactericidal Concentration bagi Listeria monocytogenes, dan pada rasio tersebut tidak ditemukan pertumbuhan Listeria monocytogenes.

$\mathrm{Hal}$ ini diduga semakin panjang rantai atom $\mathrm{C}$ dari asam-asam lemak, solubilitasnya semakin menurun, dan semakin sulit menembus membran sitoplasma. Semakin hidrofobik asamasam lemak masih cukup untuk berinteraksi dengan hidrofobik protein dan lemak-lemak pada permukaan sel bakteri. Nichols et al. (2002) menyatakan bahwa suhu inkubasi berpengaruh terhadap pertumbuhan serta kebutuhan C15:0 dan C17:0 bagi Listeria monocytogenes [15]. Pertumbuhan L. monocytogenes pada suhu inkubasi $15-21,2{ }^{\circ} \mathrm{C}$ adalah pada fase lag. Kebutuhan C17:0 lebih tinggi dibanding C15:0. Komposisi asam-asam lemak C17:0 Listeria monocytogenes dibedakan menjadi 3 region, yaitu supraoptimal $\left(42\right.$ dan $\left.45^{\circ} \mathrm{C}\right)$; optimal $\left(37^{\circ} \mathrm{C}\right)$; dan suboptimal $\left(30,20,10\right.$, dan $\left.5^{\circ} \mathrm{C}\right)$ [22]. Ross et al. (2000), menyatakan bahwa C15:0 merupakan agen aktifitas membran sel dan dalam konsentrasi tinggi akan merusak fungsi membran sitoplasma, sehingga sel Listeria monocytogenes mati [26].Asam-asam lemak mempengaruhi permeabilitas sel dan transpor nutrisi. Sejumlah mikromol asam-asam lemak dapat berpengaruh terhadap aktifitas enzim dalam membran sel. Asam lemak polyunsaturated juga dilaporkan menghambat mikroba melalui autooksidasi dan formasi peroksida [27]. Knapp and Melly (1986) melaporkan bahwa pengaruh bakterisidal dari asam lemak polyunsaturated dijembatani oleh proses peroksidasi yang melibatkan hidrogen peroksida, dan ion Fe dari bakteri. Penelitian yang dilakukan ini memperlihatkan bahwa C15:0 lebih menghambat Listeria monocytogenes dibandingkan $\mathrm{C} 17: 0$, hal ini berhubungan dengan mekanisme peroksidasi [28].

\section{KESIMPULAN}

Semakin besar rasio $\mathrm{C} 15: 0 / \mathrm{C} 17: 0$ dalam sosis fermentasi ikan lele dumbo, pertumbuhan Listeria monocytogenes makin sedikit. Sosis yang difermentasi menggunakan kombinasi Pediococcus acidilactici dan Lactobacillus casei starter memiliki rasio C15:0/C17:0 terbesar, dan 
mampu mematikan pertumbuhan Listeria monocytogenes. Rasio C15:0/C17:0 dengan nilai 79,84 merupakan dosis antilisterial (Minimum Bactericidal Concentration) pada suhu inkubasi $15-21,2^{\circ} \mathrm{C}$ secara in-vitro.

\section{DAFTAR PUSTAKA}

1. Choupoehuk,P., N. Raksakulthai, and Worawattanamateekul, 2001. Process Development of Fish Sausage. Int. Journal of Food Properties. 4 (3): $523-529$.

2. Kurokawa,T., 1979. Kamaboko-forming ability of frozen and ice stored lizard fish. Bulletin of the Japanese Society of Scientific Fisheries. 45:1551-1555.

3. Raju, C.V., Shamasundar, B.A., and Udupa, K.S., 2003. The Use of Nisin as a Preservative in Fish Sausage Stored at Ambient $(28 \stackrel{\circ}{\circ})$ and refrigerated $(6 \circ \mathrm{C})$ Temperature. Journal of food Sci. (38): 171-185.

4. Hugas,M., M.Garriga, T. Aymerich, and J.M.Montfort, 1995. In-hibition of Listeria in dry fermented sausages by the bacteriocinogenic Lactobacillus sake CTC494. J. Appl. Bacteriol. 79, 322-330.

5. Sobrino, O.J., Rodriguez, J.M., Moreira, W.L., Fernandez, M.F., Sanz, B., Hernandez, P.E., 1991. Antibacterial activity of Lactobacillus sake isolated from dry fermented sausages. Int. J. Food Microbiol. 13, 1- 10.

6. Harris, L.J., Daechel, M.A., Stiles, M.E., Klaenhammer, T.R., 1989. Antimicrobial activity of lactic acid bacteria against Listeria monocytogenes. J. Food Prot. 53, 384-387.

7. Klaenhammer, T.R., 1993. Genetics of bacteriocins produced by lactic acid bacteria. FEMS Microbiol. Rev. 12, 39-86.

8. Muriana PM, Klaenhamer TR., 1991. Purification and partial characterization of lactacin F, a bacteriocin produced by Lactobacillus acidophilus 11088. Appl. Environ. Microbiol. 57:114-121.

9. Erkkila, S, Petaja, E. 2001. Screening of commercial meat starter cultures at low $\mathrm{pH}$ and in the presence of bile salts for potential probiotic use. Meat Sci. 55: 297-300.

10. Loessner, M., S. Guenther, S. Steffan, and S. Scherer., 2003. A Pediocin-Producing Lactobacillus plantarum Strain Inhibits Listeria monocytogenes in a Multispecies Cheese. J. App. Environ. Microbiology. 69: 1854-1857.

11. Carvalho, A.A., R.A. Paula, H.C. Mantovani, C.A. Moraesa, 2005. Inhibition of Listeria monocytogenes by a lactic acid bacterium.
International Journal of Food Microbiology 59, 301- 309

12. Aryanta, R.W., Graham H. Fleet and Ken A. Buckle, 1991. The occurrence and growth of microorganisms during the fermentation of fish sausage. International Journal of Food Microbiology. 13: 143-156.

13. Nursyam, H, S.B Widjanarko, Sukoso, and Yunianta., 2006. Combination of Pediococcus acidilactici $0110<$ TAT-1 and Lactobacillus casei NRRL-B1922 starter on the Microbiological characteristic of Clarias Catfish Fermented Sausage which Infected by Listeria monocytogenes ATCC-1194. National fisheries science seminar, Agriculture Faculty, Gajah Mada University, July $26^{\text {th }} 2006$.

14. Nursyam, H, S.B Widjanarko, Sukoso, and Yunianta., 2007. The use of Pediococcus acidilactici $0110<$ TAT-1 Starter on Catfish Fermented Sausage which Infected by Escherichia coli IFO-3301 and Listeria monocytogenes ATCC-1194. National fisheries science seminar, Fisheries Faculty-UB, Apryl $24^{\text {th }} 2007$.

15. Nichols, D.S., K.A. Presser, J.Olley, T. Ross, and T.A. McMeekin, 2002. Variation of Branched-Chain Fatty Acids Marks the Normal Physiological Range for Growth in Listeria monocytogenes. Appl. and Environmental Mic. p. 2809-2813.

16. Kronval, G., 1982. Analysis of single reference strain for determination of gentamicin regression line constants and inhibiton zone diameter breakpoints in quality control of disk diffusion antibiotic susceptibility testing. J. Clin. Microbiol. 16(5) 734-793.

17. Wang L.L., and E.A. Johnson., 1992. Inhibition of Listeria monocytogenes by Fatty Acids and Monoglycerides. App. Environ. Microbiology. 12: 624-629.

18. Hamm. 1977. Analysis of Smoke and Smoken Foods. Pure and Apl.Chem. Pangomon Press. 49:1665-1666.

19. Montel, M., Reitz, J., Talon, R., Berdagué, J. and Rousset-Akrim, S., 1999. Biochemical activities of Micrococcaceae and their effects on the aromatic profiles and odours of a dry sausage model. Food Microbiol. 13: 489-499.

20. Sasser, M. 1990. Identification of bacteria through fatty acid analysis, p. 199-204. In Z. Klement, K. Rudolph, and D. Sands ed.), Methods in phytobacteriology. Akademiai Kiado, Budapest.

21. Welch, D.F., 1991. American Society for Microbiology Applications of Cellular Fatty 
Acid Analysis. Clinical Microbiology Reviews, Oct. 1991, p. 422-438.

22. Annous, B. A., L. A. Becker, D. O. Bayles, D. P. Labeda, and B. J. Wilkinson. 1997. Critical role of anteiso-C15:0 fatty acid in the growth of Listeria monocytogenes at low temperatures. Appl. Environ. Microbiol. 63:3887-3894.

23. Gutierrez, J.A., 1999. Mechanisms conferring a Rhodococcus species wigh high resistance to benzene. School of Microbiology. UNSW. Australia. Pp. 242.

24. Mastronicolis, S. K., J. B. German, and G. M. Smith. 1996. Diversity of the polar lipids of the food-borne pathogen Listeria monocytogenes. Lipids 31:635-640.

25. Weintraub, A., U. Zahringer, H.-W. Wollenweber, U. Seydel, and E. T. Rietschel. 1989. Structural characterization of the lipid A component of Bacteroides fragilis strain NCTC 9343 lipopolysaccharide. Eur. J. Biochem. 183:425-431.

26. Ross, J.A., Dalgaard., $2002 . \quad$ Dietary flavonoids, bioaviability, metabolic effect and safety. Ann. Rev. Nutr. 22: 19-34.

27. Greenway, D. L. A., and K. G. H. Dyke. 1979. Mechanism of the inhibitory action of linoleic acid on the growth of Staphylococcus aureus. J. Gen. Microbiol. 115:233-245.

28. Knapp, H. R., and M. A. Melly. 1986. Bactericidal effect of polyunsaturated fatty acids. J. Infect. Dis. 154:84-94 